\title{
PENGARUH EKSTRAK BIJI ANGGUR (VITIS VINIFERA) VAR ALPHONSO LAVALLEE TERHADAP FUNGSI GINJAL MENCIT JANTAN (MUS MUSCULUS) MODEL HIPERURISEMIA
}

\author{
Mira Wiji Lestari ${ }^{1}$, Isbandiyah ${ }^{1}$, Annisa' Hasanah ${ }^{1}$ \\ Fakultas Kedokteran, Universitas Muhammadiyah Malang \\ J1. Bendungan Sutami 188 A Malang, 65156 \\ Email : mirawijilestari@gmail.com
}

\begin{abstract}
ABSTRAK
Pengaruh Ekstrak Biji Anggur (Vitis vinivera) var Alphonso lavallee Terhadap Fungsi Ginjal Mencit Jantan (Mus musculus) Model Hiperurisemia.Latar Belakang : Prevalensi hiperurisemia di Indonesia sebesar 18\% populasi. Hiperurisemia dapat menyebabkan terjadinya disfungsi ginjal.Kreatinin merupakan salah satu parameter untuk mengukur fungsi ginjal.Terjadinya disfungsi ginjal dapat dicegah menggunakan biji anggur var Alphonso lavallee.Biji anggur ini memiliki kandungan polifenol tinggi terutama proanthocyanidin, flavonoid, dan resveratrol yang berfungsi sebagai antiinflamasi, antioksidan, inhibisi COX-2, dan meningkatkan produksi NO.Tujuan:Mengetahui pengaruh ekstrak biji anggur var Alphonso lavallee terhadap fungsi ginjal mencit jantan (Mus musculus) model hiperurisemia.Metode : Eksperimental, The Post Test Only Control Group Design. Sampel terdiri dari 30 ekor mencit jantan yang dibagi menjadi 5 kelompok diantaranya kelompok kontrol , kontrol + , dam 3 kelompok perlakuan. Semua kelompok kecuali kontrol - diinduksi dengan kalium oksonat $250 \mathrm{mg} /$ $\mathrm{kg} /$ hari dan 3 kelompok perlakuan diberi ekstrak biji anggur var Alphonso lavallee dengan dosis $3.5 \mathrm{mg} / \mathrm{ekor}$ mencit/hari, $7 \mathrm{mg} /$ ekor mencit/hari, dan $14 \mathrm{mg} /$ ekor mencit/hari peroral selama 7 hari. Kreatinin serum diukur menggunakan spektrofotometer untuk menilai fungsi ginjal mencit.Analisis data menggunakan uji One way ANOVA, post boc bonferroni, dan uji regresi.Hasil Penelitian : Ekstrak biji anggur var Alphonso lavallee dapat menurunkan kadar kreatinin serum secara signifikan dengan $\mathrm{p}<0.001$ pada dosis mulai dari $7 \mathrm{mg}$ /ekor mencit/hari.Kesimpulan : Ekstrak biji anggur var Alphonso lavallee berpengaruh dalam mencegah terjadinya kerusakan fungsi ginjal pada mencit hiperurisemia.
\end{abstract}

Kata kunci : Biji anggur var Alphonso lavallee, polifenol, fungsi ginjal, kalium oksonat

\begin{abstract}
Effects of Grape Seed (Vitis vinifera) var Alphonso lavallee Extracts for Renal Function in Male Hyperuricemic Mice (Mus musculus).Background : The prevalence of Hyperuricemia in Indonesia amounted to $18 \%$ of population. Hyperuricemic is associated with renal dysfunction. Serum creatinine is one of parameter to measure renal function. Renal dysfunction caused by hyperuricemia can be prevented by grape seed var Alphonso lavallee which has a high polyphenols content particularly proanthocyanidin, flavonoid and resveratrol that posses various biological effects including anti-inflammation, anti-oxidant, COX-2 inhibition, increase of NO production. Objective : This study was to evaluate the effects of grape seed var Alphonso lavallee extracts for renal function in male hyperuricemic mice (Mus musculus). Methods : This study used experimental, the post only control group design. The sample consisted of 30 male mice were devided into 5 groups, including negative control, positive control, and 3 treatment groups. All group except for negative control induced with potassium oxonate at dose $250 \mathrm{mg} / \mathrm{kg} /$ day and 3 treament groups were also given grape seed var Alphonso lavallee extracts orally at dose $3.5 \mathrm{mg} / \mathrm{mice} /$ day, $7 \mathrm{mg} / \mathrm{mice} /$ day, and $14 \mathrm{mg} / \mathrm{mice} /$ day for 7 days. Serum creatinine levels were determined by spectrophotometer to evaluate renal function in mice. Data were analized using one way ANOVA, Post hoc bonferroni and Regression test.Results : Grape seed var Alphonso lavallee extracts significantly $(\mathrm{p}<0.001)$ decreased serum
\end{abstract}


creatinine at dose $7 \mathrm{mg} / \mathrm{mice} /$ day.Conclusion : Grape seed var Alphonso lavallee extracts has nephroprotective effects on hyperuricemic mice.

Keywords : Grape seed var Alphonso lavallee, polyphenols, renal function, potassium oxonate

\section{PENDAHULUAN}

Hiperurisemia adalah keadaan dimana kadar asam urat lebih besar dari $7.0 \mathrm{mg} / \mathrm{dl}$ pada laki-laki dan lebih besar dari $6.0 \mathrm{mg} / \mathrm{dl}$ pada perempuan (Prasad Sab OS, Qing YX, 2015). Meningkatnya kadar asam urat dapat disebabkan oleh berbagai faktor diantaranya diet tinggi purin atau protein, konsumsi alkohol yang berlebihan, adanya kondisi turnover sel maupun gangguan pada enzim yang memetabolisme purin (Busuioc M, 2007). Meningkatnya kadar asam urat atau hiperurisemia dapat berkembang menjadi gout dan juga disfungsi ginjal. Dari hasil studi epidemiologi, didapatkan prevalensi terjadinya hiperurisemia di Indonesia sebesar 18\% (Smith E, 2015). Menurut Zhou B et al, lebih dari $40 \%$ pasien gout pada akhirnya mengalami CKD (Chronic Renal Disease) (Zhou B, 2014). Sebuah studi menunjukkan dari 13.000 partisipan dengan fungsi ginjal normal, terdapat peningkatan resiko terjadinya penyakit ginjal sebanyak $7 \%$ dengan peningkatan $1 \mathrm{mg} / \mathrm{dL}$ dari serum asam urat (Viazzi F, 2011).

Hiperurisemia berkontribusi secara patologis terhadap terjadinya vasokonstriksi pada renal, disfungsi endotel akibat inhibisi NO (Nitric Oxide), peningkatan respon inflamasi salah satunya adalah IL-1â (Interleukine-1â), stres oksidatif, sistem RAS (Renin Angiotensin System), dan COX-2 (Cyclooxygenase-2) yang umumnya terjadi pada $A R F$ (Acute Renal Failure) dan pada akhirnya berkembang menjadi CKD. Salah satu penyebab disfungsi ginjal adalah adanya stres oksidatif akibat asam urat, sehingga untuk mencegah hal tersebut dibutuhkan antioksidan.Antioksidan yang dapat berpotensi salah satunya ada pada biji anggur yangmengandung polifenol tinggi yang dapat berfungsi sebagai antioksidan (Godevac D, 2010). .

Polifenol pada biji anggur diantaranya adalah proanthocyanidin, anthocyanin dan resveratrol.Aktifitas antioksidan dari polifenol yang ada pada biji anggur lebih tinggi dibandingkan antioksidan yang telah banyak diketahui seperti vitamin C, vitamin E, dan betakaroten (Hussein S, 2015). Selain itu, polifenol yang dapat diekstraks sebesar 10\% atau kurang pada daging buah, 60$70 \%$ pada biji, dan 28-35\% pada kulit buah anggur. Proanthocyanidin dapat berperan sebagai vasodilator, menghambat interleukin-6, TNF-á serta cyclooxygenase2, menginduksi NO dan juga memiliki pengaruh secara non-kompetitif dalam menghambat aktivitas dari xanthin oksidase yang merupakan salah satu pembangkit radikal bebas (Limtrakul P, 2016).

Anggur var alphonso lavallee merupakan salah satu varietas unggul yang ada di Indonesia.Anggur ini memiliki kandungan phenolic, antocyanin, catechin, dan procyanidin yang tinggi dan terdistribusi paling banyak pada biji anggur Hasil penelitian menunjukkan bahwa biji anggur var alphonso lavallee mengandung fenol sebanyak 105,3 \pm 6,1 mg GAE (Gallic Acid Equivalents)/g (Bozan B, 2008).

Berdasarkan uraian diatas, maka penulis ingin mengetahui pengaruh ekstrak biji anggur var alphonso lavallee terhadap fungsi ginjal mencit jantan model hiperurisemia dengan menilai kadar kreatinin serum. Kreatinin merupakan parameter yang sering digunakan untuk menilai fungsi ginjal dimana hasil metabolit kreatin ini secara bebas difiltrasi oleh glomerulus (Rodrigues WF, 2014).

\section{BAHAN DAN METODE PENELITIAN}

\section{Hewan Coba}

Hewan coba yang digunakan adalah mencit jantan (Mus musculus) yang diambil secara acak dengan berat $20 \pm 2 g$, usia $3-6$ bulan, dengan kondisi sehat yang ditandai dengan gerakan yang aktif dan mata jernih. Mencit diaklimatisasi dahulu dengan lingkungan dan pakan standar BR-1 selama 7 hari di Laboratorium Biomedik Fakultas Kedokteran Universitas Muhammadiyah Malang sebelum dilakukan perlakuan sambil diamati kesehatanya. 30 ekor mencit diambil secara acak dan dibagi kedalam 5 kelompok diantaranya kelompok 1 ( kelompok kontrol negatif) yaitu kelompok tanpa perlakuan yang hanya diberi pakan standart, kelompok 2 
(kelompok kontrol positif) yaitu kelompok yang diberi kalium oksonat $5 \mathrm{mg} /$ ekor mencit/hari, kelompok 3 yaitu kelompok yang diberi kalium oksonat $5 \mathrm{mg} /$ ekor mencit/hari dan ekstrak biji anggur sebanyak $3.5 \mathrm{mg} /$ ekor mencit/hari, kelompok 4 yaitu kelompok yang diberi kalium oksonat $5 \mathrm{mg} /$ ekor mencit/hari dan ekstrak biji anggur sebanyak $7 \mathrm{mg} /$ ekor mencit/hari, dan kelompok 5 yaitu kelompok yang diberi kalium oksonat $5 \mathrm{mg} /$ ekor mencit/hari dan ekstrak biji anggur sebanyak $14 \mathrm{mg} /$ ekor mencit/hari. Perlakuan diberikan pada hewan coba selama 7 hari berturut-turut.

\section{Induksi Obat}

Kalium oksonat digunakan untuk menginduksi peningkatan kadar asam urat pada mencit. Kalium oksonat yang digunakan didapat dari Sigma-Aldrich. Kalium oksonat diberikan dengan dosis $250 \mathrm{mg} / \mathrm{kg} /$ hari dilarutkan terlebih dahulu dengan $15 \mathrm{ml}$ aquades dan diberikan peroral dengan sonde selama 7 hari.

Pembuatan, Penentuan Dosis, dan Pemberian Ekstrak Biji Anggur

Buah anggur dipisahkan dari bijinya, kemudian biji dibersihkan dari sisa daging yang masih melekat setelah itu dikeringkan (di tempat teduh, suhu udara $25-30^{\circ} \mathrm{C}$ selama 1 minggu dan digiling menjadi bubuk halus.Bubuk biji anggur (100g) diekstraksi dengan soxblet extractor dengan petroleum ether pada suhu 60ÚC selama 6 jam. Setelah itu diekstrak ulang selama 8 jam dengan mengunakan $200 \mathrm{ml}$ campuran etil asetat : metanol : air (60:30:10). Filtrat yang didapatkan dipekatkan di rotary evaporator pada suhu 70ÚC.

Dasar penentuan dosis berdasarkan jurnal yang berjudul "Effect of grape seed extract on renal ischaemic reperfusion in Rats" dimana dalam jurnal tersebut dijelaskan tentang efek proteksi ginjal pada studi in vivo bahwa dengan pemberian $250 \mathrm{mg} /$ kg ektrak biji anggur pada tikus. Untuk mengetahui efek dengan menggunakan dosis lebih rendah dan juga lebih tinggi. Maka pada penelitian digunakan dosis $125 \mathrm{mg} / \mathrm{kg}, 250 \mathrm{mg} / \mathrm{kg}$, dan $500 \mathrm{mg} / \mathrm{kg}$. Setelah itu, dosis pada tikus dikonversi ke dalam dosis mencit didapatkan hasil dosis $3.5 \mathrm{mg} /$ ekor mencit, $7 \mathrm{mg} /$ ekor mencit, dan $14 \mathrm{mg} /$ ekor mencit. Masing-masing dosis ektrak diberikan peroral melalui sonde 1 jam setelah pemberian kalium oksonat pada masing-masing 3 kelompok perlakuan.
Proses Anastesi, Pengambilan Sampel Darah, dan Pengukuran Kadar Kreatinin Serum

Proses anastesi dilakukan satu per satu terhadap hewan coba yaitu dengan memasukkan hewan coba ke dalam toples kaca yang berisi kapas yang sudah dicampur dengan kloroform.

Setelah hewan coba teranastesi dengan baik (keadaan pingsan), hewan coba diletakkan pada meja lilin dan keempat kaki hewan coba difiksasi terhadap meja lilin dengan menggunakan jarum pentul.Masukkan jarum diantara sisi kiri dari processus xiphoideus dan costae terakhir.Seketika masuk ke kulit, tarik bagian plugger spuit untuk memberikan tekanan negatif di dalam tabung spuit.Kemudian masukkan jarum secara perlahan ke kavum toraks menuju jantung dengan sudut antara 40-45 derajat. Ketika sejumlah kecil darah sudah masuk, stabilkan spuit dan tarik plugger perlahan-lahan, ambil sampel \pm 1 cc (Mc Gill, 2009). Sampel kemudian disentrifus dengan kecepatan $3000 \mathrm{rpm}$ selama 15 menit dan diambil serumnya untuk pemeriksan kadar ureum dan kreatinin.

Pengukuran kadar kreatinin serum dilakukan dengan oleh peneliti dengan didampingi laboran menggunakan spektrofotometer yang di lakukan di Laboratorium Biomedik Universitas Muhammadiyah Malang.

\section{Analisis Data}

Hasil penelitian dianalisis menggunakan uji normalitas dengan metode Shapiro-Wilk, uji homogenitas Levene',uji ANOVA, uji post hoc beferroni, uji korelasi menggunakan analisis regresi linier dengan menggunakan aplikasi SPSS 19.

\section{HASIL PENELITIAN}

Hasil penelitian, didapatkan hasil kadar kreatinin serum sebagai berikut :

\begin{tabular}{lcl}
\hline Perlakuan & $\begin{array}{l}\text { Kadar Kreatinin se rum } \\
\text { (mg/dL) } \\
\text { ( Rerata } \pm \text { Stand ar } \\
\text { Deviasi }\end{array}$ \\
\hline Nomal & 2.92 & \pm 0.49 \\
Kontrol Posi tif & 6.33 & \pm 0.41 \\
P 1 (Perlakuan 1) & 5.83 & \pm 0.52 \\
P 2 (Perlakuan 2) & 4.83 & \pm 0.41 \\
P 3 (Perlakuan 3) & 3.92 & \pm 0.38 \\
\hline
\end{tabular}


Tabel diatas menunjukkan bahwa rerata kadar kreatinin serum pada kelompok kontrol negatif sebesar $2.92 \mathrm{mg} / \mathrm{dL}$. Kelompok kontrol positif yaitu kelompok yang hanya diberi kalium oksonat selama 7 hari memiliki rerata sebesar 6.33 $\mathrm{mg} / \mathrm{dL}$. Pada kelompok perlakuan yang diinduksi dengan kalium oksonat dan diberi dengan ekstrak biji anggur var Alphonso lavallee, kelompok perlakuan 1 dengan dosis ekstrak biji anggur $3.5 \mathrm{mg} /$ ekor mencit/hari memiliki rerata kadar kreatinin serum sebesar $5.83 \mathrm{mg} / \mathrm{dL}$, kelompok perlakuan 2 dengan dosis $7 \mathrm{mg}$ /ekor mencit/hari memiliki rerata 4.83 $\mathrm{mg} / \mathrm{dL}$, sedangkan kelompok perlakuan 3 dengan dosis $14 \mathrm{mg} /$ ekor mencit/hari memiliki rerata sebesar $3.92 \mathrm{mg} / \mathrm{dL}$.

Hasil uji normalitas diperoleh nilai $\mathrm{p}>$ 0.05 yang dapat disimpulkan bahwa distribusi data bersifat normal. Sedangkan uji homogenitas (levene test) untuk mendeteksi adanya kesamaan ragam didapatkan nilai $\mathrm{p}=0.863$. Karena nilai $\mathrm{p}>0.05$ maka varian data bersifat homogen.Sehingga syarat untuk dilakukan uji One way ANOVA terpenuhi.

Hasil uji oneway ANOVAmenunjukkan nilai $\mathrm{p}<0.05$ berarti terdapat perbedaan bermakna antara kadar kreatinin serum kelompok perlakuan yang diberi dosis tertentu ekstrak biji anggur var Alphonso lavallee dengan kadar kreatinin serum pada kelompok kontrol. Karena uji One way ANOVA menunjukkan bahwa terdapat perbedaan yang bermakna, maka untuk mengetahui pada kelompok mana yang memiliki perbedaan bermakna, maka dilakukan uji Post hoc. Dari hasil uji Post bocmenunjukkan bahwa hanya antara kelompok kontrol positif dengan kelompok perlakuan 1 (dosis ekstrak biji anggur var Alphonso lavallee $3.5 \mathrm{mg} /$ ekor mencit/hari) yang menunjukkan tidak berbeda signifikan. Sedangkan antar kelompok yang lain menunjukkan berbeda signifikan karena diperoleh nilai $\mathrm{p}<0.05$.

Berdasarkan hasil uji regresi didapatkan nilai koefisien korelasi $(r)$ sebesar 0,910. Sehingga dapat disimpulkan bahwaekstrak biji anggur var Alphonso lavallee memiliki pengaruh yang sangat kuat terhadap kadar kreatinin serum mencit jantan yang diinduksi kalium oksonat. Selain itu, pada uji regresi diatas didapatkan persamaan sebagai berikut:

$$
\mathrm{Y}=6.317+(-0.178) \mathrm{X}
$$

Keterangan:

$\mathrm{Y}=$ kadar kreatinin serum
$\mathrm{X}=$ dosis ekstrak biji anggur var Alphonso lavallee

Aplikasi dari persamaan diatas adalah untuk memprediksi penurunan kadar kreatinin serum pada mencit yang diinduksi kalium oksonat selama 7 hari bila mencit tersebut diberi ekstrak biji anggur var Alphonso lavallee dengan dosis lain yang tidak diteliti. Untuk menilai kualitas persamaan hasil analisis regresi linier, dapat dinilai dengan melihat hasil uji $A N O V A$ yang ada pada statistik uji regresi.Suatu persamaan dikatakan layak untuk digunakan bila nilai $\mathrm{p}<0.05$. Pada uji anova didapatkan $\mathrm{p}=0.000$ sehingga persamaan diatas layak untuk digunakan. Hasil juga menunjukan bahwa adjusted $\mathrm{R}$ square sebesar 0.820 , sehingga dapat dikatakan bahwa dosis ekstrak biji anggur var Alphonso lavallee berpengaruh terhadap penurunan kadar kreatinin serum sebesar (adjusted $\mathrm{R}$ square $\mathrm{x} 100)=82 \%$. Sisa presentase $18 \%$ menunjukkan bahwa penurunan kadar kreatinin serum pada penelitian ini dipengaruhi oleh faktor lain selain dosis ekstrak biji anggur var Alphonso lavallee.

\section{PEMBAHASAN}

Berdasarkan hasil penelitian dan analisis statistik menunjukkan bahwa pemberian ekstrak biji anggur var Alphonso lavallee dapat menurunkan kadar kreatinin serum mencit jantan yang diinduksi kalium oksonat. Pada penelitian ini, induksi oksonat ditujukan untuk meningkatan kadar asam urat dalam darah,dimana asam urat ini dapat menyebabkan terjadinya kerusakan fungsi ginjal (Busuioc M, 2007).

Kalium oksonat bekerja dengan cara menghambat enzim urikase sehingga asam urat tidak dapat berubah menjadi alantoin untuk diekskresikan,sehingga kadar asam urat meningkat. Hal ini sesuai dengan penelitian sebelumnya dimana mencit yang diberi kalium oksonat dengan dosis $250 \mathrm{mg} / \mathrm{kg} /$ hari selama 7 hari menunjukkan peningkatan kadar ureum yang signifikan dari 4.91 $\mathrm{mg} / \mathrm{dL}$ menjadi $7.37 \mathrm{mg} / \mathrm{dL}$ (Chen YS, 2013).

Peningkatan kadar asam urat dapat menyebabkan terjadinya kerusakan fungsi ginjal. Hal ini dikarenakan asam urat menyebabkan vasokonstriksi ginjal dan disfungsi endotel akibat terjadinya stres oksidatif dan respon inflamasi ${ }^{2}$.Stres oksidasi timbul akibat reaksi xanthin oksidase dalam proses metabolisme asam urat. Adanya stress oksidasi menyebabkan inhibisi produksi NO (Nitric oxide). Penurunan produksi NO menyebabkan terjadinya 
disfungsi endotel yang berhubungan erat dengan terjadinya hipertensi.Hipertensi sendiri dapat menyebabkan gangguan pada pembuluh darah kecil terutama pada pembuluh darah preglomerulus ginjal (Prasad Sab OS, 2015).

Asam urat akan masuk ke dalam sel otot polos vaskular (VSMC (Vascular Smooth Muscle Cell) melalui transporter anion organic (OAT). Di dalam VSMC, asam urat akan mengaktivasi protein kinase P38 maupun Erk1/2 yang mempengaruhi faktor transkripsi nuklear NF-KB dan AP-1 untuk menghasilkan fenotip proliferasi dan proinflamasi, sehingga otot polos vaskular dari pembuluh darah memproduksi COX2, senyawa vasokostriktif (angiotensin II, tromboksan $\mathrm{A}_{2}$ ), sitokin, dan molekul proinflamasi (C-reactive protein (CRP), monocytechemoattractan protein-1 (MCP-1). COX2 dan TXA2 menyebabkan peningkatan ekspresi dari faktor pertumbuhan (platelet-derived growth factor (PDGF)) yang menyebabkan proliferasi VSMC. Proliferasi sel, peningkatan ekspresi senyawa vasokonstriktif, dan infiltrasi makrofag akibat ekspresi MCP-1, menyebabkan dinding pembuluh darah preglomerulus menebal dan terjadi arteriolopati preglomerulus. Hal ini menyebabkan hipoperfusi yang berakhir menjadi injuri ginjal. Selain itu, injuri ginjal juga dapat disebabkan akibat asam urat melalui aktivasi RAS dan juga peningkatan faktor proinflamasi IL1â, IL6, dan TNFá. Disfungsi ginjal dapat dinilai dengan kadar kreatinin serum.

Peningkatan asam urat pada akhirnya dapat menyebabkan kerusakan ginjal yang ditunjukkan dengan peningkatan kadar kreatinin serum. Hal ini sesuai dengan hasil penelitian yang dilakukan yaitu pada mencit kelompok kontrol positif yang diberi kalium oksonat dengan dosis $250 \mathrm{mg} / \mathrm{kg} / \mathrm{hari}$ pada mencit selama 7 hari, memiliki rerata kadar kreatinin serum sebesar $6.33 \mathrm{mg} / \mathrm{dL}$. Pada mencit kelompok kontrol negatif didapatkan rerata kadar kreatinin serum sebesar 2.92. Hasil penelitian ini sesuai dengan penelitian sebelumnya yang menunjukkan bahwa pemberin kalium oksonat dengan dosis $250 \mathrm{mg} / \mathrm{kg} /$ hari menyebabkan peningkatan kreatinin serum yang signifikan sejalan dengan peningkatan kadar asam urat. Namun dengan hasil kadar serum kreatinin yang meningkat tersebut belum dapat dipastikan bahwa mencit jantan telah mengalami disfungsi ginjal. Hal ini disebabkan karena hasil dari berbagai penelitian yang menggunakan kalium oksonat dengan dosis
$250 \mathrm{mg} / \mathrm{kg} /$ hari selama 7 hari berbedabeda.Penelitian yang dilakukan Shi YW et al menunjukkan peningkatan yang signifikan dari \pm 0.98 menjadi $\pm 1.18 \mathrm{mg} / \mathrm{dL}$, penelitian Chen YSet al menunjukkan peningkatan dari 0.89 menjadi 1.06 $\mathrm{mg} / \mathrm{dL}$. Sedangkan penelitian Wang Ret al menunjukkan peningkatan dari 0.99 menjadi 1.24 $\mathrm{mg} / \mathrm{dL}$, namun meskipun tidak diketahui secara pasti terjadi disfungsi ginjal, pada penelitian ini disebutkan bahwa ginjal mencit mengalami perubahan histopatologi yaitu terjadi dilatasi tubular pada ginjal dan degenerasi vakuolar sel epitel tubular.

Hasil kreatinin serum peneliti berbeda jauh dengan hasil pada penelitian terdahulu. Hal ini karena peneliti menggunakan Jaffe Methods untuk mengukut kadar serum kreatinin. Jaffe methods memiliki hasil perhitungan kadar kreatinin yang overestimasi akibat pengaruh dari kromatogen nonkreatinin (Dunn SR, 2004).

Penelitian menunjukkan bahwa dengan pemberian ekstrak biji anggur var Alphonso lavallee memiliki korelasi atau hubungan yang sangat kuat $(\mathrm{r}=0.910)$ dalam mencegah peningkatan kadar kreatinin serum kelompok perlakuan yang lebih rendah dibanding kontrol positif. Hambatan ini diduga disebabkan karena biji anggur mengandung banyak senyawa polifenol yaitu flavonoid, proanthocyanidin, dan resveratrol.Senyawa polifenol secara umum telah diketahui memiliki fungsi sebagai antioksidan dan juga antiinflamasi.Flavonoid dan proanthocyanidin diketahui dapat menghambat aktivitas xanthin oxidase, COX-2, TNF-á, IL-6,dan MCP-1. Selain itu proanthocyanidin juga dapat meningkatkan produksi NO sama seperti resveratrol.

Hal ini sesuai dengan beberapa penelitian terdahulu bahwa ekstrak biji anggur dapat menurunkan terjadinya stres oksidatif dan TNF-á pada organ testis akibat pengaruh paparan asap rokok pada tikus. Selain itu, pada penelitian lain menunjukkan bahwa ekstrak proanthocyanidin biji anggur meningkatkan aktivitas enzim antioksidan dan menurunkan kadar protein c-reactive, ekspresi TNF-á, MCP-1pada ginjal tikus diabetes tipe-2. Selain itu ekstrak proanthocyanidin biji anggur meningkatkan nitric oxide endotel pada tikus yang dibuat hipertensi. Resveratrol memiliki aktivitas nefroprotektif pada mencit hiperurisemia yang diinduksi oleh kalium oksonat melalui regulasi organic ion transporter. Dan juga proanthocyanidin (ekstrak beras merah) menghambat IL-6, TNF-á, COX-2 
pada sel Raw 264.7 macrophages melalui hambatan AP-1, NF-êB,dan MAPK.

Hasil uji regresi didapatkan persamaan $\mathrm{Y}$ $=6.317+(-0.178) \mathrm{X}$. Persamaan diatas digunakan untuk memprediksi penurunan kadar kreatinin serum bila mencit tersebut diberi ekstrak biji anggur var Alphonso lavallee dengan dosis lain yang tidak diteliti atau sebaliknya yaitu untuk memprediksi dosis yang diperlukan agar kadar kreatinin mencit yang diinduksi kalium oksonat selama 7 hari sama dengan kadar kelompok kontrol negatif. Pada hasil penelitian didapatkan rerata 2.92 , bila dimasukkan pada persamaan diatas, maka didapatkan dosis sebesar 19,10 mg/ekor mencit/hari. Dari hasil penelitian didapatkan dosis minimal ekstrak biji anggur var Alphonso lavallee yang memberikan efekadalah 7 $\mathrm{mg} /$ ekor mencit/hari karena menunjukkan penurunan kadar kreatinin serum yang signifikan. Pada dosis $3.5 \mathrm{mg} /$ ekor mencit/hari,meskipun memiliki kadar kreatinin serum yang lebih rendah dibandingkan dengan kontrol positif, namun perbedaan kadar tersebut tidak memiliki perbedaan yang signifikan.

Pengaruh dosis pemberian ekstrak biji anggur var Alphonso lavallee dalam menghambat terjadinya disfungsi ginjal akibat peningkatan kadar asam urat sebesar $82 \%$ sedangkan 18\% sisanya dipengaruhi oleh faktor lain selain dari pemberian ekstrak biji anggur. Sebab peningkatan atau penurunan asam urat dan kreatinin dipengaruhi oleh beberapa faktor, baik dari faktor endogen maupun eksogen. Kreatinin adalah hasil metabolit kreatin yang utamanya diproduksi oleh otot skelet yang kemudian secara bebas akan difiltasi dalam glomerulus. Oleh karena itu, massa otot berpengaruh terhadap kadar kreatinin, dimana usia secara tidak langsung akan berpengaruh karena pada usia yang lebih tua, jumlah massa otot akan menurun. Sehingga bisa digunakan parameter lain untuk mengetahui apakah terdapat peningkatan secara statistik pengaruh hambatan ekstrak biji anggur terhadap terjadinya disfungsi ginjal akibat peningkatan kadar asam urat pada mencit yang diberi kalium oksonat. Disebutkan pula bahwa inulinclearance -GFR adalah gold standart dalam dalam pengukuran fungsi ginjal baik pada studi hewan maupun pada klinis. Selain itu dapat dipengaruhi oleh genetik dari mencit meskipun mencit yang digunakan dari spesies yang sama. Pada mencit dengan gen tertentu memiliki kecenderungan memiliki kadar asam urat yang lebih tinggi.

Faktor eksogen yang dapat berpengaruh terhadap kreatinin serum adalah jumlah diet pada mencit. Telah diketahui bahwa kadar asam urat didapat dari endogen dan eksogen. Dengan penggunaan kalium oksonat, apabila terdapat peningkatan intake protein juga lebih meningkatan kadar asam urat dibandingkan dengan intake protein yang sedikit karena kalium oksonat menghambat asam urat menjadi allantoin untuk diekskresikan dan juga meningkatkan xanthine debydrogenase maupun xanthine oxidase. Sehingga dapat diasumsikan terjadi peningkatan jumlah asam urat yang masuk dalam VSMC (Vasculaar Smooth Muscle Cell) yang menyebabkan progresifitas disfungsi ginjal ${ }^{15}$. Selain itu dapat dipengaruhi juga oleh proses pembuatan ekstrak, kondisi lingkungan, hormonal, perlakuan hewan coba selama penelitian dan metode atau proses pengukuran kadar kreatinin serum menggunakan spektrofotometer. Penelitian yang dilakukan hanya menggunakan post test only control design sehingga tidak diketahui adakah kelainan pada mencit sebelum dilakukan perlakuan yang dapat menyebabkan terjadinya bias.

\section{KESIMPULAN}

Berdasarkan hasil yang diperoleh dari penelitian dapat disimpulkan bahwa ekstrak biji anggur var Alphonso lavallee dapat mencegah terjadinya disfungsi ginjal pada mencit yang diinduksi kalium oksonat. Namun belum diketahui secara pasti pada tahapan mana hambatan tersebut dalam patofisiologi terjadinya disfungsi ginjal akibat peningkatan kadar asam urat karena dalam penelitian ini hanya mengukur kadar kreatinin serum. Kreatinin merupakan salah satu parameter untuk menilai fungsi ginjal.

\section{DAFTAR PUSTAKA}

Bozan B, Tosun G, Ozcan D, 2008, Study of Polyphenol Content in The Seeds of Red Grape (Vitis vinifera L.) Varieties Cultivated in Turkey and Their Antiradical Activity, Food Chemistry, 109 , 426-430.

Breyer MD, Qi Z, 2010, Better Nephrology for Mice and Man, Kidney International, 77, 487-489. 
Busuioc M, Voroneanu L, Hogas S, et al. 2007, Pathogenic Impact of Hyperuricemia in Renal and Cardiovascular Disease, BANTAO journal, 5(1),1.

Chen YS, Hu QH, Zhang X, et al. 2013,Beneficial Effect on Rutin on Oxonate-Induced Hyperuricemia and Renal Dysfunction in Mice, Pharmacology, 92, 75-83.

Cui X, Liu X, Feng H, et al. 2012, Grape Seed Proanthocyanidin Extracts Enhance Endothelial Nitric Oxide Synthase Expression Through 5'AMP Activated Protein Kinase/Surtuin 1-Krupple Like Factor 2 Pathway and Modulate Blood Pressure in Ouabain Induced Hypertensive Rats, The Pharmacentical Society of Japan, 35(12), 2192-2197.

Dunn SR, Qi Z, Bottinger EP, 2004, Utility of Endogenous Creatinine Clearance As a Measure of Renal Function in Mice, Kidney International, 65, 1959 - 1967.

Filiopoulos V, Hadjiyannakos D, Vlassopoulos D, 2011,New Insights into Uric Acid Effects on the Progression and Prognosis of Chronic Kidney Disease, CIN.

Godevac D, Tesevic V, Velickovic M, et al. 2010, Poliphenolic Compounds in Seeds From Some Grape Cultivars Grow in Serbia, Journal of the Serbian Chemical Society, 75 (12), 1641-1652.

Hashemi M, et al. 2012, Effect of grape seed extract on renal ischaemic reperfusion in Rats, Journal of Animal and Veterinary Advance, vol 11 (14), 25292532.

Hussein S, Abdrabba S, 2015, Physico-chemical Characteristics, Fatty Acid, Composition of Grape Seed Oil and Phenolic Compounds of Whole Seeds, Seeds and Leaves of Red Grape in Libya, International Journal of Applied Science and Mathematics, vol.2, issue 5, 2394-2894.

Kang DH, Nakagawa T, 2005,Uric Acid and Chronic Renal Disease: Possible Implication of Hyperuricemia on Progression of Renal Disease, Research Gate.

Limtrakul P, Yodkeeree S, Pitchakarn P, et al. 2016, Antiinflammatory Effects of Proanthocyanidin-rich Red Rice Extract Via Suppression of $M A P K$, AP-1 and NF-êB Pathways in Raw 264.7 Macrophages, Nutrition Research and Practice, 10(3), 251-258.

Prasad Sah OS, Qing YX, 2015, Associations Between Hyperuricemia and Chronic Kidney Disease : A
Review, Nephrology and Urology Reseach Center, 7(3), e27233.

Rodrigues WF, Miguel CB, Napimoha MH, et al. 2014, Establishing Standards for Studying Renal Function in Mice Through Measurements of Body Size Adjusted Creatinine and Urea Levels, Biomed Research International, 872827.

Shi YW, Wang CP, Lie L, et al. 2012, Antibyperuricemic and Nephroprotective Effects of Resveratrol and its Analogues in Hyperuricemic Mice, Molecular Nutrient Food Research, 1-12.

Smith E, Marshal L, 2015, Global Prevalence of Hyperuricemia: A Systematic Review of PopulationBased Epidemiological Studie', American College of Rheumatology, 2236.

Viazzi F, Leoncini G, Pontremoli R, 2011,Cardiovascular and Renal Effects of Hyperuricaemia and Gout, Reumatismo, 64(4), 253-262.

Wang R, MA Chun H, Zhou F,et al.2016,Siwn Decoction Attenuates Oxonate-Induced Hyperuicemia and Kidney Inflammation in Mice, Chinese Journal of Natural Medicine, 14(7), 0499-0507.

Zhou B, Chen T, Liu C, et al. 2014, IL-1â is Related to Hyperuricemic Nephropathy Induced by HighPurine Diet, Gout and Hyperuricemia, 1(4), 151 156. 